\title{
Rapeseed: how to value varieties with higher nitrogen use efficiency in France ${ }^{\star}$
}

\author{
Edwige Charbonnier, Aline Fugeray-Scarbel* and Stéphane Lemarié \\ Univ. Grenoble Alpes, INRA, CNRS, Grenoble INP, GAEL, 38000 Grenoble, France
}

Received 5 February 2019 - Accepted 15 April 2019

\begin{abstract}
This article focuses on the interest in improving the nitrogen use efficiency of rapeseed varieties in France. We show that this trait is of interest at different levels of the value chain and for different markets. Nitrogen use efficiency improves farmers' margins by reducing fertilizing costs or increasing yields. Nitrogen use efficiency also improves the GHG (greenhouse gas) balance of rapeseed used for biodiesel production and the image of edible rapeseed oil for consumers within the framework of specific labels. Finally, nitrogen use efficiency can also be seen as a trait that improves the protein content of rapeseed oilcake and, therefore, increases its value compared to competing sources of protein. After a detailed presentation of these different valuations, we provide current or possible measures that have been or could be implemented to encourage different actors in the sector to develop and diffuse this trait.
\end{abstract}

Keywords: rapeseed / nitrogen / plant breeding / economic value / value chain

\begin{abstract}
Résumé - Colza : quelle valorisation pour des variétés plus efficientes en azote dans le contexte français ? Cet article porte sur l'intérêt économique de variétés plus efficientes en azote pour la filière colza dans le contexte français. Nous montrons que ce caractère présente des intérêts à différents niveaux de la filière et pour différents débouchés. L'efficience en azote permet d'améliorer la marge des agriculteurs en diminuant leurs dépenses en engrais ou en augmentant le rendement. Elle permet également d'améliorer le bilan GES (gaz à effet de serre) du colza destiné à la production de biodiesel, et d'améliorer l'image de l'huile alimentaire de colza vis à vis des consommateurs dans le cadre de labels spécifiques. Enfin, l'efficience azotée peut être vue aussi comme un caractère permettant d'améliorer de contenu protéique des tourteaux de colza et donc mieux les valoriser par rapport aux sources de protéines concurrentes. Après avoir présenté plus en détail ces différentes valorisations, nous étudions les dispositifs actuels ou qui pourraient être mis en place pour encourager différents acteurs de la filière à développer et diffuser ce caractère (the full text is available in French on https://www.ocl-journal.org/10.1051/ocl/2019021/olm).
\end{abstract}

Mots clés : colza / azote / sélection variétale / valeur économique / filière

With 1.4 million hectares (ha) and 5.4 million tons (Mt) of seed produced each year, rapeseed is the most widely grown oilseed crop in France. France is thus the leading European rapeseed producer, ahead of Germany, contributing to making the European Union (EU) the world's leading producer, ahead of Canada and China (Terres Univia, 2017).

Originally grown to produce edible oil for human nutrition and oilcake for animal feed, rapeseed was challenged during the 1970 s and 1980 s because of its erucic acid content (harmful for human health) and its glucosinolate content (problematic for animal feed). The selection of " 00 " rapeseed varieties ${ }^{1}$ (without erucic acid or glucosinolates) during the 1980s, as well as the increase of biofuels (during the 1990s), have led to a revaluation of the crop, whose area has more than tripled in France over the past 40 years.

Today, rapeseed faces new challenges: competition from soybean and palm in the oil market and from soybean meal - rich in protein - for animal feed, as well as new regulations on greenhouse gas (GHG) emissions for biofuel production. In this context, improving the nitrogen balance of rapeseed

\footnotetext{
‡ The French version is available in "Supplementary Material".

*Correspondence: aline.fugeray-scarbel@inra.fr
}

\footnotetext{
1 " 00 " rapeseed varieties in France is the equivalent of Canola in Canada.
} 
cultivation is a crucial issue to ensure the sector's long-term competitiveness. Various levers are possible to improve this balance, including the genetic improvement of varieties for nitrogen-efficient traits and the improvement of cultivation practices to optimise the nitrogen supply. It is also important to understand how nitrogen efficiency is valued at different levels of the supply chain and benefits (or not) economic stakeholders.

In this paper, we are particularly interested in the development of varieties that are more nitrogen-efficient. To date, high nitrogen-efficient varieties, identified as such, are not available in the European market. However, there is some genetic variability in rapeseed, suggesting that this trait can be improved. Indeed, the "conventional" selection in Europe has enabled significant genetic progress, which can be measured by increasing yields for similar or even decreasing nitrogen inputs. Finally, research programmes are specifically designed to improve the nitrogen efficiency of varieties. For example, the aim of the RAPSODYN project is to produce tools and knowledge that will enable breeders to accelerate genetic progress of this trait using conventional breeding. The impact of such results on commercialized varieties is expected to be observable in approximately ten years. The potential for valorizing these future varieties is therefore an important question, as it is a lever for their development.

This article is organized in three parts. We first present the different markets for rapeseed (edible oil, biofuels and oilcake) and its positioning compared to its competing alternatives in each of these markets. Second, we present the interests of nitrogen-efficient rapeseed varieties of these different outlets and how they can be developed to strengthen the competitive advantage of rapeseed over alternatives presented. Finally, we analyse the mechanisms or initiatives that are currently being established or could be established to encourage the economic actors in the sector to improve the general nitrogen balance. These mechanisms may be regulatory or established by the stakeholders in the rapeseed value chain.

For this analysis, we first conducted a literature review, presenting a current overview of the rapeseed sector in France. This review was based on bibliographic data on the organization of the rapeseed sector in France and its evolution and outlets, as well as the main regulations and the quality systems put in place by the actors. This summary was completed by twelve semi-directive interviews conducted with key players in the rapeseed sector: one breeder, two institutional representatives of the breeding sector, two cooperatives and distributors, one technical institute, two representatives of rapeseed producers, three industrialists specialized in rapeseed process, and one institutional representative of the biofuels sector.

\section{Rapeseed outlets and their positioning compared to alternatives}

In France, rapeseed is grown on 1.4 million hectares. Rapeseed is the fourth most common crop cultivated in France, and it is grown by 73000 farmers. Due to the significant increase in yields between the 1970s (19 qx/ha) and the mid1990s (38.2 qx/ha in 2017; Terres Univia, 2017), rapeseed production has sharply increased to $5 \mathrm{Mt}$, representing nearly $80 \%$ of the total oilseed production in France.
The rapeseed grains that are produced are crushed to extract their oil. The solid residues obtained at the end of this crushing process constitute the oilcake by-product. Rapeseed production is distributed over three main markets: the oil is used for human consumption (refined edible oil) or for biofuel production (semi-refined oil) and oilcake for animal feed. For each of these markets, rapeseed competes with other products (other vegetable oils, biofuels and meal produced from other crops). In this section, we present the advantages and disadvantages of rapeseed compared to these alternatives.

\subsection{Edible oil}

Edible oil is obtained after refining the crude oil, thus avoiding the formation of undesirable compounds and the degradation of constituents of nutritional interest. A total of $25 \%$ of the rapeseed oil produced is refined by this process, representing a volume of 500000 tons. Rapeseed oil is mainly used as food for human consumption (and to a lesser extent for animal feed and oleochemistry). More than $80 \%$ of this edible oil is used in out-of-home catering and food processing industries. Household consumption of rapeseed oil accounts for only a very small share.

At the end of the 1960s, the image of rapeseed food oil was tarnished by studies showing the negative impact on health of the erucic acid found in the seeds (cardiovascular risks). The industry quickly reacted by selecting and distributing varieties without erucic acid, known as " 0 " varieties. Since then, rapeseed oil has been looked upon favourably by consumers. It is known for its nutritional qualities, in particular its linolenic acid (omega-3) and linoleic acid (omega-6) content and its richness in vitamin E (GNIS Pédagogie). However, dietary habits largely favour sunflower and olive oils. Thus, in supermarkets, rapeseed oil represents only $10 \%$ of vegetable oil sales. As rapeseed oil consumption is closely linked to its image among consumers, it is its quality that can enable it to withstand competition from these alternatives.

\subsection{Oil for biofuel production}

To produce biofuels, rapeseed oil is semi-refined, as it only requires partial refining. It is then combined with an alcohol, methanol, to form a biodiesel, termed VOME - Vegetable Oil Methyl Ester. The resulting VOME is then mixed with diesel fuel and can be used in diesel engines.

The cost of producing biofuels, including rapeseed biodiesel, is higher compared to fossil fuels. Therefore, this biofuel cannot be marketed without public support. This support is justified to facilitate the energy transition, and in this case, to promote renewable energies and limit GHG emissions related to fuel use. This support has had a major impact on the rapeseed sector in France, since $75 \%$ of the rapeseed oil produced in France is used to produce biodiesel.

In France, two tax incentives have been introduced: a partial exemption of the domestic consumption tax on energy products granted to biofuels (until 2015) and an additional levy of the general tax on polluting activities for fuel distributors with a biofuels proportion below a minimum threshold (Cour des Comptes, 2016).

In addition to these tax measures, rapeseed biofuels have benefited from European regulations that encourage or require 
a minimum incorporation rate of biofuels into fossil fuels. These incorporation rates have varied between $2 \%$ (end of 2005 ) and $5.15 \%$ (end of 2010) and reach 10\% (the target for 2020 set in Directive 2009/28/EC). This incorporation rate was then reduced to a maximum of $7 \%$ for biofuels produced from cereals, sugar and oilseeds (Directive (EU) 2015/1513) to take into account the indirect land use changes linked to the development of these crops. Finally, since 2009, biofuel sustainability criteria have also been considered: biodiesel has to lead to an overall GHG reduction of at least 35\% compared to that of fossil fuels (until 2016). This reduction percentage increased to $50 \%$ from the first of January 2017 and $60 \%$ from the first of January 2018 for installations in which production started on or after the first of January 2017.

Biodiesel from rapeseed is largely competing with palm biodiesel and soybean biodiesel from Argentina. This competition is mainly economic; the production costs are very low, and the subsidies for soybean biodiesel in Argentina is high. It has been further strengthened in the last few months for two reasons. First, regulatory changes have led to the removal of some tariff barriers (anti-dumping duties) that were previously applied to imports of palm and soybean biodiesel. Second, palm oil has become more competitive due to the development of the HVO technology, which consists in hydrogenation to make it more fluid and prevent it from freezing (Capital, 2018).

These other types of biofuels may nevertheless be disadvantaged, to the benefit of rapeseed biodiesel, if GHG balance regulations evolve to take into account the Direct or Indirect Land Use Change (dLUC and ILUC). This measure would also affect rapeseed biodiesel but to a lesser extent. This measure would also lead to the promotion of new competing biofuels produced from non-food feedstocks. Finally, in a context where diesel is being challenged in favour of gasoline, various biodiesels are more clearly competing with their alternative for gasoline engines, namely, bioethanol produced mainly from maize, sugar cane, beet or wheat.

\subsection{Oilcake for animal feed}

In 2014, France produced 2.369 Mt of rapeseed meal; $0.408 \mathrm{Mt}$ was exported, and $0.520 \mathrm{Mt}$ was imported. The total consumption of rapeseed meal thus amounts to $2.481 \mathrm{Mt}$, slightly more than $30 \%$ of the feed cakes consumed in France. Rapeseed oilcakes are used for feeding cattle, pigs and poultry.

In the early $1980 \mathrm{~s}$, genetic selection reduced the level of glucosinolates in rapeseed, which were responsible for the loss of appetite in cattle and physiological disorders in monogastric animals (pigs and poultry) (Terres Univia). The varieties currently used for animal feed are called " 00 " (lacking erucic acid and with low glucosinolate content).

Rapeseed meal is in competition with soybean meal, which is widely used in animal feed, particularly because of its high protein content ( $45 \%$ compared to $34 \%$ for rapeseed meal). However, rapeseed meal has interesting nutritional properties and particularly good levels of sulfur amino acids and lysine (CETIOM, 2001). Rapeseed oilcakes from European production also have the advantage of being non-GMO. In addition, the increase in rapeseed production (for biofuels) is leading to an increase in the supply of meal, which is helping to increase the use of rapeseed oilcakes in feed rations for farmed animals.
The interest in rapeseed meal compared to soybean meal depends in fact on its price relative to its quality (protein content). To improve the competitiveness of rapeseed against soybean, it is therefore necessary to improve its quality or, if its protein content remains the same, to reduce its production cost.

\section{Nitrogen-efficient varieties are of potential interest at different levels of the supply chain, depending on the outlets}

We saw in the previous section that, depending on the outlets, rapeseed competes with other products (e.g., soybean and palm oil, olive and sunflower oil, and soybean oilcake). The positioning of rapeseed in comparison to these alternatives depends, in each case, on its price, quality, or environmental impact. The adoption of more nitrogen-efficient varieties may have potential advantages to favour rapeseed products over the competitors.

In this section, we show that these interests are multiple and concern different levels of the supply chain and different outlets. First, we show that the use of more nitrogen-efficient varieties is of economic interest, regardless of the outlet, because it increases the crop's gross margin for the farmer. Then, we show that these varieties also have a positive impact that varies according to the outlet: these varieties can improve the GHG balance of biofuels, contribute to improving the image of the edible oil or increase the protein content of oilcakes.

\subsection{Economic valorization in rapeseed production}

Rapeseed varieties can be more nitrogen efficient if the crop yield is higher for the same nitrogen supply or if they need less nitrogen fertilizer for the same yield. In both cases, nitrogen efficiency results in an economic gain for the farmer. For the same yield, nitrogen efficiency contributes to a decrease in the production costs through savings on nitrogen inputs and, consequently, an increase in the gross margin of the crop. As fertilizers represent the main source of variable costs in rapeseed cultivation (between one-third and one-half), their use has a strong impact on farmers' gross margins.

The economic interest of these nitrogen-efficient varieties is determined by the cost of the seed-savings in inputs must not be offset by an additional seed cost - and by the performance of the varieties in other criteria (oil content, pest resistance, tolerance to climatic hazards, etc.).

Finally, the interviewees in our study noted that varieties with a higher yield for a constant nitrogen supply are more easily adopted than varieties with an equivalent yield for a lower nitrogen use. Farmers would perceive them more positively. Indeed, promoting a new variety with a better yield is generally easier than encouraging farmers to decrease nitrogen fertilization.

\subsection{Environmental benefits of nitrogen-efficient varieties}

Nitrogen fertilization directly impacts the crop's GHG balance in two ways. The first way concerns the production of fertilizers, i.e. the production of synthetic nitrogen. The production of synthetic nitrogen uses natural gas as a raw material for the production of ammonia, and it emits nitrous 
oxide $\left(\mathrm{N}_{2} \mathrm{O}\right)$ for the production of nitric acid that is necessary for the production of ammonium nitrate (UNIFA, 2012). The second way concerns the spreading of nitrogenous fertilizers, resulting in nitrous oxide emissions. These emissions are the result of biological processes in the soil (nitrification and denitrification, in particular) ${ }^{2}$. The use of nitrogen-efficient rapeseed varieties, therefore, has a direct impact on the crop's GHG balance, since the varieties either limit the use of nitrogen fertilizers for an equivalent yield or increase the crop's yield for the same amount of nitrogen.

Nitrogen fertilization can also contribute to leaching, which corresponds to the transport of nitrate ions by rainwater. Nitrogen ions can reach rivers either vertically (infiltration from the soil into the groundwater) or horizontally by surface runoff. This leaching causes pollution of groundwater and rivers, which is particularly problematic in some French regions. To avoid this leaching, it is necessary to carefully compile the amount of nitrogen fertilizer applied so that it is in line with the crop's needs and to apply it immediately before the plant absorbs it. Therefore, if the use of nitrogen-efficient varieties is not expected to reduce this leaching phenomenon, their adoption must go hand-in-hand with a fertilization rationale, to adapt the level of inputs used to these varieties.

\subsubsection{Valuation in the context of GHG balance for biofuels}

The improvement of the GHG balance of rapeseed cultivation through the use of nitrogen-efficient varieties is particularly valuable for the biofuels market. Biofuels have to reduce GHGs by 50 to $60 \%$ compared to fossil fuels to be considered "sustainable", to be taken into account in the incorporation objectives, and to receive public support. These emissions are calculated over the whole production cycle (farming, processing, transport, and distribution). However, the default values for rapeseed biodiesel are $52 \mathrm{gCO}_{2} \mathrm{eq} / \mathrm{MJ}$, corresponding to a $38 \%$ reduction compared to diesel. To demonstrate, through independent certification, the compliance of biomass and biofuels with sustainability requirements, French stakeholders of the biofuel and crop production sectors have established the voluntary 2BSvs scheme (Biomass Biofuels Sustainability voluntary scheme; FOP, 2015a). This scheme aims to establish a GHG balance sheet over the entire chain, calculated using real values at the agricultural and industrial level. The objective is to verify that the reduction in GHG emissions is greater than the regulatory threshold of $50 \%$. In this context, the use of more nitrogen-efficient varieties would lessen the environmental impact of rapeseed biodiesel, as emissions from rapeseed production in the field are the most important in the overall balance, and as nitrogen fertilizer is the main source of rapeseed crop emissions.

\subsubsection{Image enhancement for edible oil}

The use of more nitrogen-efficient varieties for the production of edible oil can lead to a positive image among

\footnotetext{
${ }^{2}$ These processes can occur in the plot receiving the nitrogen input (direct emission) or outside the plot (indirect emission promoted by nitrogen transfers in the form of $\mathrm{NH}_{3}, \mathrm{NO}_{x}$ and $\mathrm{NO}_{3}{ }^{-}$).
}

consumers who are increasingly concerned regarding the environmental impact of the products they consume.

\subsection{Protein valuation}

More nitrogen-efficient rapeseed varieties could, in some cases, be richer in protein, leading to an improvement in the quality of the oilcake produced from these varieties. The increase in the protein content of the oilcakes would lead to a better valorization of the latter, making them more competitive with soybean.

Beyond protein content, the quality of protein is of particular importance, as certain types of protein could be of interest for the health, chemistry, etc. sectors. Research is also ongoing regarding the characterization of rapeseed proteins for food purposes, as they are much less well characterized than milk and soybean proteins, creating a competitiveness differential regarding their use.

The use of more nitrogen-efficient rapeseed varieties has therefore several potential benefits: an economic benefit through an increase in the gross margin of the crop, an environmental benefit that improves the GHG balance of biofuels produced from rapeseed oil and enhances the image of rapeseed edible oil, and an improved quality of rapeseed meal with potentially increased protein content. These different valuations of nitrogen efficiency reinforce the interest in rapeseed products (oils and oilcake) compared to their alternatives presented in the first part. In the next section, we present how the stakeholders in the value chain can promote nitrogen-efficient rapeseed varieties and valorize their interests.

\section{Levers to improve the value of more nitrogen-efficient varieties}

Certain actions taken by stakeholders in the value chain can encourage the development and diffusion of more nitrogenefficient varieties. These levers can be used from the upstream level (breeding) to the downstream level (storage and processing of rapeseed products). Some of these levers already exist, such as the "Fleur de Colza" label for edible oil and the "Biodiesel Progress Approach" created to support farmers and storage organizations. Other levers are being developed, such as the evolution of the criteria for variety registration and the adaptation of tools used to calculate the required amount of nitrogen fertilizer. Finally, there are potential levers that have not been implemented at the moment: calculation of GHG emissions at the plot level, a specific storage for harvests from nitrogen-efficient varieties, and fine characterization of rapeseed proteins.

\subsection{Variety registration}

The VCU criteria (Value for Cultivation and Use), which must be met by varieties to be included in the French Official Catalogue, guide the selection of varieties by breeders. These criteria are defined by the CTPS (Permanent Technical Committee for Plant Breeding) and can evolve according to the orientations of the sector and societal needs. However, these criteria are constrained by the registration rules defined in other European countries. Indeed, excessive requirements in 
France could lead seed companies to register their varieties in other European Union countries, which would not prevent them from marketing them in France because these varieties would be registered in the European catalogue.

\subsubsection{Varietal tests with limited nitrogen supply}

For several years, the CTPS and the GEVES (French Variety and Seed Study and Control Group) have been working on the question of nitrogen fertilization of rapeseed, under the impetus of the "Seeds and Sustainable Agriculture" action plan launched by the French Ministry of Agriculture in 2011. This plan led to the integration of an environmental value into the criteria for the registration of varieties in the Catalogue ${ }^{3}$. From the 2012/2013 season onwards, nitrogen inputs were reduced by 40 units throughout the GEVES experimental network. The system thus makes it possible to register varieties that are $a$ priori more nitrogen-efficient, if the yield meets the requirements of the specifications.

However, the CTPS technical regulation does not, to date, provide any particular valuation for varieties that are more nitrogen-efficient (e.g. a "nitrogen bonus" to facilitate the registration of such varieties). On the other hand, breeders may request, on a case-by-case basis, a special experiment under the conditions they propose - for example, strong nitrogen restriction - if they assume the full costs of the tests.

For the time being, the CTPS does not plan to modify the experimental network to test varieties under conditions of stronger nitrogen restriction. According to one stakeholder interviewed, this position is justified because the guidelines must not be too restrictive, otherwise they will be bypassed via the European Catalogue. Ideally, different levels of reduction should be tested to better highlight their impacts; however, this is not possible due to the limited budget. As nitrogen efficiency is a complex issue, some interviewees noted that the main objective for the CTPS and GEVES would be to identify indicators to better highlight nitrogen efficiency. This objective would help to promote varieties with this trait.

\subsubsection{Considering protein content for variety registration}

Currently, there is a requirement for measuring protein content to register oilseed rape varieties (CTPS, 2017). In the case of restored hybrid " 00 ", it is the relationship between yield and protein content that is assessed. A bonus or penalty is applied to the variety's rating, based on its results compared to those of the control varieties. For other types of varieties, the difference between the protein content of the variety and that of the control varieties is measured and is assigned a coefficient of 0.5 and is included in the variety quotation.

This requirement for measuring protein content is a priori a lever to enhance the value of the most nitrogen-efficient varieties, when they allow a better yield at constant nitrogen supply. This leverage could be strengthened by introducing a minimum threshold for protein content, or by providing as much weight to the protein content (currently assigned a

\footnotetext{
${ }^{3}$ The translation of VCU in french is VAT ("Valeur Agronomique et Technologique"). The action plan led to the addition of the "E" and the acronym VATE ("Valeur Agronomique, Technologique et Environnementale").
}

coefficient of 0.5 ) as to the oil content in variety ratings. However, more nitrogen-efficient varieties will not necessarily have a higher protein content. Moreover, beyond the protein content, their quality is also to be considered.

\subsection{Agricultural practices and extensional services}

\subsubsection{Development of tools to calculate the nitrogen dose}

The recommendations for nitrogen fertilization of the French extension services have significantly progressed since the early 1990s, with the development of tools such as the "réglette azote" for rapeseed and the Farmstar service. Producers thus have at their disposal a large set of tools to support their decisions, as well as crop management guides tested and promoted by the Terres Inovia extension service. These tools help farmers adjust nitrogen inputs to crop needs. These tools are gradually gaining ground, in a context that favours an evolution towards agro-ecological practices: societal demand, the Nitrates Directive, regulations on biofuels, the search to optimize production costs, etc. Research is now moving towards the development of global monitoring tools; the objective is to enable farmers to monitor their rapeseed at a much larger scale, using a combination of measurement and diagnostic tools for biomass production (drones, satellites, Farmstar, etc.). These results are translated into a fertilizer plan, plot-by-plot. Progress in agricultural machinery has also enabled management adjustment at the intra-plot level.

The deployment of new, more nitrogen-efficient varieties will have to be accompanied by appropriate advisory services for farmers, both regarding the use of these varieties and the issues they help to address. Thus, a number of rules about nitrogen fertilization management, currently based on the use of "standard" varieties, will have to be adapted to these new varieties and integrated into decision support tools; farmers should be encouraged to use these tools.

\subsubsection{The "Biodiesel Progress Approach" (survey and advice to farmers)}

The "Progress Approach" was initiated in 2007 by the interprofessional group of oil-protein crops (FOP, 2015b). This text acknowledges the willing of the sector's stakeholders to continuously improve the environmental impact of biodiesel, from the upstream agricultural sector (farmers, cooperatives and agricultural traders) to the downstream industrial sector (logistics and industrial sites). The objective of the agricultural part of this programme is to support farmers and storage organizations in more sustainable practices. SAIPOL has been the most active biodiesel producer in implementing this interprofessional agreement by mobilising storage agencies as part of contracts for its rapeseed supply. This DIESTER ${ }^{R}$ progress approach is based on two types of actions. First, farm surveys are annually conducted on a significant number of plots (representing at least $10 \%$ of the rapeseed collection area of each cooperative or trader). These surveys consist of collecting yield and crop management data, including data about nitrogen fertilization, to obtain an assessment of the GHG performance of rapeseed plots. Second, action plans are implemented by storage agencies in farmers' fields; for nitrogen (use of decision support tools or valorization of the 
nitrogen from legumes), for yield (search for solutions to improve yield or reduce losses in the field by promoting advanced cutterbars) and through demonstration/experimental approaches (implementation of trials using protocols proposed by Terres Inovia to acquire references on innovations that will improve nitrogen efficiency). These action plans aim to identify farming practices adapted to different soil and climate contexts to improve the GHG balance.

However, progress on the agricultural part of the programme remains very limited, particularly due to low adoption of the approach by farmers. Farmers are not well informed regarding the approach and its stakes, and do not benefit from it in their farm. Indeed, the storage agencies are paid $€ 4$ per ton of rapeseed contracted with SAIPOL, but this amount is mainly used to cover administrative management costs and data collection. Farmers do not benefit from individualized feedback of the data collected on their plots.

However, this approach would be an interesting lever to enhance the nitrogen efficiency of varieties, by measuring the impact of the adoption of more efficient varieties and by establishing specific experiments for these varieties.

\subsection{Storage and processing}

Nitrogen efficiency is valued downstream of the production chain for production of rapeseed as a whole. Thus, with a few exceptions, if a farmer has production for which nitrogen has been more efficiently used, this production will not be sold with a premium. We first present the only case that is, to our knowledge, an exception to the rule. We then discuss the conditions to improve the value of "high nitrogen efficiency" production downstream of the chain.

\subsubsection{Labels for edible oil ("Fleur de colza")}

Terres OléoPro, the French vegetable oil and protein industry brand, has been developing a Commitment Charter since 2016. This charter has been specifically designed for brands whose products use oil-protein seeds. The purpose of this charter is to guarantee to consumers that their products use seeds that are sown, grown, harvested, stored and processed in France and that the production process meets quality criteria (good agricultural practices, respect for the environment, etc.). The products concerned can be identified in stores thanks to the logo of the Terres OléoPro chain brand on the packaging. The edible oil brand Fleur de Colza (Lesieur) is therefore engaged in this approach (Terres Oléopro, 2016).

The use of more nitrogen-efficient rapeseed varieties could be among the measures promoted by the brand's specifications, thus contributing to their development.

\subsubsection{Differentiating farm gate prices}

As previously mentioned, for a large portion of the rapeseed production in France, farm gate prices are uniform, limiting farmers' incentives to adopt practices that would improve nitrogen use. This incentive would be stronger if farmers could better sell productions that requires less nitrogen per unit of production. However, several conditions are necessary.
The first condition is to have a simple indicator that differentiates productions with respect to their nitrogen efficiency. This indicator should also be relatively inexpensive to measure, and recognized by stakeholders, to provide better downstream valuation. Concerning the main outlet for rapeseed, biodiesel, methodologies for calculating GHG balances can be used to differentiate rapeseed according to its GHG performance, and these performances could easily be taken into account downstream, via mass balance systems. However, the calculation methodologies certified by the European Commission are more restrictive than those used to establish the NUTS 2 flat-rate values. This restriction therefore encourages the use of NUTS 2 flat-rate values rather than trying to improve agricultural practices, as any progress is difficult to value using the methodologies currently certified. In addition, it seems difficult to compile actual values for the agricultural part by analysing the crop management of each of the fields harvested, as this would be too complex and costly. Several interlocutors interviewed during our survey noted that the variety could be a very simple indicator, if some varieties were recognized as having better nitrogen efficiency. However, this indicator would not provide information regarding the adaptation of nitrogen management to the variety, or on the expression of production potential which may be limited by factors other than nitrogen.

In some cases, it may also be necessary to be able to separate the harvesting of high-nitrogen-efficient rapeseed from "traditional" rapeseed. This is the case when the value provided by this efficiency requires a separation of the production after the harvest and would occur under a scenario where the objective would be to produce oil cakes that are richer in protein. For the human food market, as part of an initiative, such as Fleur de Colza, the choice of a nitrogen-efficient variety could simply be included on the list of measures encouraged by the brand's specifications. Under this scenario, the harvest of this variety can be mixed with the harvests that meet these specifications with other criteria. Finally, in the case of biodiesel, this separation is generally not necessary due to the use of certificates. More precisely, the grain is dissociated from the certificate that guarantees the level of GHG emissions. In other words, these certificates are sufficient to preserve the added value associated with nitrogen efficiency at the agricultural production level.

A specific storage for high-nitrogen-efficient rapeseed would be easier for the storage agencies if the volume concerned was sufficiently large. In the case of low volume, this differentiation will only be possible if the added value of high nitrogen efficiency rapeseed is very significant. In any case, the implementation of differentiated value chains would require a period of adaptation, both for farmers and storage agencies. Finally, this differentiation requires that operators have a downstream economic interest, for example, through edible oil with a low environmental impact or oil cakes that are richer in protein. This premium for efficient rapeseed should also benefit farmers. Tripartite contracts between industries, storage agencies and farmers could therefore be considered, setting the amount of the premium allocated to more nitrogen-efficient rapeseed. 


\section{Conclusion}

In this paper, we have shown that obtaining more nitrogenefficient rapeseed varieties is of interest for all rapeseed outlets. However, nitrogen efficiency will not be defined in the same manner for each outlet, suggesting that different types of varieties should be defined to meet these different needs. Thus, varieties whose nitrogen efficiency consists in increasing the protein content of the production, while maintaining the same yield level, will be of interest for oil cakes that would see their quality improved. However, these varieties will not be of interest for biofuels because the GHG balance will not be modified. On the other hand, varieties for which nitrogen efficiency would increase yield while maintaining the same protein content will be valuable for the biofuels market (improvement of the GHG balance) but will not have an impact on oilcake quality.

This antagonism between yield and protein content exists for other crops. In wheat, for example, the varieties are differentiated according to their protein content: varieties rich in protein (strong wheat) have a lower yield potential than varieties termed BPS (Superior Bread Wheat); these varieties are separately stored and are sold at a higher price per quintal. Such segmentation could be considered for rapeseed varieties if the evolution of the market (quantity produced and demand for these varieties) allows.

\section{Supplementary Material}

French version.

The Supplementary Material is available at https:/www.ocljournal.org/10.1051/ocl/2019021/olm.

Acknowledgements. This research was funded as part of the Projet Investissements d'Avenirs (PIA) RAPSODYN. This project involves a consortium of sixteen public and private partners over a period exceeding seven years, with the aim of creating more nitrogen-efficient rapeseed varieties. We would like to thank all the people we interviewed for this study as well as Annick Bellamy (INRA), Jean-Eric Dheu (Limagrain), Nathalie Nesi (INRA), Luc Ozanne (Sofiprotéol) and Xavier Pinochet (Terres Inovia) for their participation in the steering committee that supervised this study. The analyses produced here are the sole responsibility of the authors of this paper.

\section{References}

Capital. 2018. Agrocarburants : le match huile de palme-colza en cinq questions, 11 juin 2018. Disponible sur https://www.capital.fr/ economie-politique/agrocarburants-le-match-huile-de-palme-col za-en-cinq-questions-1292378 (dernière consult. 2019/07/02).
CETIOM. 2001. Le tourteau de colza, une source de protéines équilibrée en alimentation animale. Disponible sur http://www. terresinovia.fr/fileadmin/cetiom/kiosque/PDF_fiches_TK/ co_tourteaux.pdf (dernière consult. 2019/07/02).

Cour des Comptes. 2016. «Les biocarburants: des résultats en progrès, des adaptations nécessaires ». Dans: Le rapport public annuel 2016. Tome II. L'organisation, les missions, les résultats, 2016. Disponible sur https://www.ccomptes.fr/sites/default/files/ EzPublish/RPA2016-Tome-2-integral.pdf (dernière consult. 2019/07/02).

CTPS. 2017. Règlement technique d'examen des variétés de colza oléagineux en vue de leur inscription au Catalogue Officiel Français. Disponible sur https://info.agriculture.gouv.fr/gedei/site/bo-agri/ document_administratif-e7c591c7-5dca-44ef-be62-57e6 da03d35c/telechargement (dernière consult. 2019/07/02).

FOP. 2015a. Durabilité des biocarburants : schéma 2BSvs. Disponible sur http://www.fopoleopro.com/durabilite-des-biocarburantsschema-2bsvs/ (dernière consult. 2019/07/02).

FOP. 2015b. La démarche de progrès. Disponible sur http://www. fopoleopro.com/la-demarche-de-progres-2/ (dernière consult. 2019/07/02).

GNIS Pédagogie. Débouchés: 1'huile alimentaire. Disponible sur https://www.gnis-pedagogie.org/colza-debouche-huile-alimen taire.html (dernière consult. 2019/07/02).

Journal officiel de l'Union Européenne. 2009. Directive 2009/28/CE du Parlement européen et du Conseil du 23 avril 2009 relative à la promotion de l'utilisation de l'énergie produite à partir de sources renouvelables et modifiant puis abrogeant les directives 2001/77/ CE et 2003/30/CE. Disponible sur https://eur-lex.europa.eu/ legal-content/FR/TXT/PDF/?uri=CELEX:32009L0028\&from=fr (dernière consult. 2019/07/02).

Journal officiel de l'Union Européenne. 2015. Directive (EU) $n^{\circ} 2015 / 1513$ du Parlement européen et du Conseil du 9 septembre 2015 modifiant la directive 98/70/CE concernant la qualité de l'essence et des carburants diesel et modifiant la directive 2009/28/CE relative à la promotion de l'utilisation de l'énergie produite à partir de sources renouvelables. Disponible sur https://eur-lex.europa.eu/legal-content/FR/TXT/PDF/?uri= CELEX:32015L1513\&from=FR (dernière consult. 2019/07/02).

Terres OléoPro. 2016. Fleur de Colza, 1er partenaire de Terres OléoPro. Disponible sur http://www.terresoleopro.com/fleur-decolza-1er-partenaire-de-terres-oleopro (dernière consult. 2019/ 07/02).

Terres Univia. 2017. Chiffres clés oléagineux et plantes riches en protéines 2017 (Édition 2018), 32 p. Disponible sur http://www. terresunivia.fr/sites/default/files/chiffres $\% 20 \mathrm{cl} \% \mathrm{C} 3 \% \mathrm{~A} 9 \mathrm{~s} /$ Terre sUnivia-chiffresCles-2017-protected.pdf (dernière consult. 2019/07/02).

Terres Univia. Graines oléagineuses. Disponible sur http:/www. terresunivia.fr/produitsdebouches/alimentation-animale/grainesoleagineuses (dernière consult. 2019/07/02).

UNIFA. 2012. Guide méthodologique pour le calcul du bilan des émissions de gaz à effet de serre. Disponible sur https://unifa.fr/ images/stories/actu/guide\%20sectoriel\%20ges-mai\%202012.pdf (dernière consult. 2019/07/02).

Cite this article as: Charbonnier E, Fugeray-Scarbel A, Lemarié S. 2019. Rapeseed: how to value varieties with higher nitrogen use efficiency in France. OCL 26: 26. 